\title{
Case report: Acute hepatitis E infection with coexistent glucose-6-phosphate dehydrogenase deficiency
}

\author{
Amitabh Monga MD, Ravinder PS Makkar MD, Anju Arora MD, Surabhi Mukhopadhyay MD, Ajay K Gupta MD
}

\begin{abstract}
A Monga, RPS Makkar, A Arora, S Mukhopadhyay, AK Gupta. Case report: Acute hepatitis $\mathrm{E}$ infection with coexistent glucose-6-phosphate dehydrogenase deficiency. Can J Infect Dis $2003 ; 14(4): 228-229$.

Hepatitis E virus is one of the leading causes of acute viral hepatitis in India but usually manifests as a mild self-limiting illness. Viral hepatitis in the presence of glucose-6-phosphate dehydrogenase (G6PD) deficiency may be associated with complications such as severe anemia, hemolysis, renal failure, hepatic encephalopathy and even death. The incidence of G6PD deficiency in the general population of northern India is reported to be between 2.2\% and 14\%. Despite both hepatitis E infection and G6PD deficiency being common, their impact on patient illness has only recently been reported. The present study reports a case of severe hemolysis in a patient with G6PD deficiency and hepatitis E infection.
\end{abstract}

Key words: Glucose-6-phosphate dehydrogenase; G6PD; Hemolysis; Hepatitis E

\section{Exposé de cas : Hépatite $\mathrm{E}$ aiguë en présence d'un déficit en glucose-6-phosphate-déshy- drogénase}

\begin{abstract}
Le virus de l'hépatite E est l'une des principales causes d'hépatite aiguë en Inde, mais il s'agit en général d'une maladie bénigne, spontanément résolutive. Par contre, une hépatite virale en présence d'un déficit en glucose-6-phosphate-déshydrogénase (G6PD) peut donner lieu à des complications comme une anémie grave, l'hémolyse, l'insuffisance rénale, une encéphalopathie porto-cave et même la mort. L'incidence du déficit en G6PD dans la population en général dans le Nord de l'Inde varie entre 2,2 et $14 \%$. Même si l'hépatite $\mathrm{E}$ et le déficit en G6PD sont deux affections fréquentes, on ne fait état de leur influence sur l'évolution de la maladie que depuis peu. Voici un cas d'hémolyse grave chez un patient atteint à la fois d'un déficit en G6PD et d'une hépatite E.
\end{abstract}

$\mathrm{H}_{\mathrm{t}}^{\mathrm{e}}$ epatitis $E$ is an enterically transmitted virus and is one of the most common causes of acute viral hepatitis in India (1). Glucose-6-phosphate dehydrogenase (G6PD) deficiency is found in $2.2 \%$ to $14 \%$ of the general population in North India (2). The coexistence of viral hepatitis and G6PD deficiency has been reported to be associated with severe jaundice and other complications $(3,4)$. Hepatitis E infection with G6PD deficiency has been associated with more severe illness in only one previous report (5). We report an additional case.

\section{CASE REPORT}

A 35-year-old man with no history of alcoholism or liver disease presented with low grade fever, upper abdominal pain, fatigue and loss of appetite for eight to 10 days. He had noticed a yellow discolouration of the eyes for three days and dark coloured urine for five to six days. On examination, he was deeply icteric. Abdominal examination revealed a soft, tender liver, palpable $4 \mathrm{~cm}$ below the costal margin. There was no splenomegaly and the remainder of the physical examination was normal.

Laboratory investigations revealed a hemoglobin mass concentration of $126 \mathrm{~g} / \mathrm{L}$, a total leucocyte count of $12.2 \times 10^{9} / \mathrm{L}$, and a total serum bilirubin of $198 \mu \mathrm{mol} / \mathrm{L}$ with a conjugated fraction of $141 \mu \mathrm{mol} / \mathrm{L}$. The serum aspartate aminotransferase (AST) concentration was $376 \mathrm{U} / \mathrm{L}$ and the alanine aminotransferase (ALT) concentration was $270 \mathrm{U} / \mathrm{L}$. The prothrombin time was $15 \mathrm{~s}$ (control: $12 \mathrm{~s}$ ). Immunoglobulin ( $\mathrm{Ig}$ ) $\mathrm{M}$ anti-hepatitis $\mathrm{A}$ virus, hepatitis B surface antigen, IgM anti-hepatitis B core and anti-hepatitis $C$ virus were negative, while $\operatorname{IgM}$ antihepatitis E virus (HEV) was positive. A diagnosis of HEV hepatitis was made and the patient was managed conservatively.

Over the next three weeks, the serum bilirubin peaked at $964 \mu \mathrm{mol} / \mathrm{L}$ (conjugated fraction: $533 \mu \mathrm{mol} / \mathrm{L}$ ), AST peaked at $1415 \mathrm{U} / \mathrm{L}$, and ALT peaked at $2184 \mathrm{U} / \mathrm{L}$. The hemoglobin mass concentration decreased to $80 \mathrm{~g} / \mathrm{L}$. The peripheral blood smear showed polychromasia, anisopoikilocytosis and reticulocytosis (the reticulocyte count was $14.6 \%$ ). Urine was positive for hemoglobinuria. The serum lactate dehydrogenase concentration was $696 \mathrm{U} / \mathrm{L}$ (normal: 200 to $500 \mathrm{U} / \mathrm{L}$ ) and serum haptoglobin was undetectable. Direct and indirect Coomb's tests were negative. Both the peripheral blood smear and the antigen-test were negative for malaria. Normal serum ceruloplasmin levels and the absence of Keyser-Fleischer rings on slit lamp examination excluded Wilson's disease. The G6PD level was $3.9 \mathrm{U} / \mathrm{gHb}$ (normal range: $4.6 \mathrm{U} / \mathrm{gHb}$ to $13.5 \mathrm{U} / \mathrm{gHb}$ ).

The patient was managed conservatively, including avoiding all hepatotoxic, nephrotoxic and oxidant drugs, and maintaining an adequate urine output. The metabolic parameters

Department of Internal Medicine, Sitaram Bhartia Institute of Science Eु Research, New Delhi, India

Correspondence: Dr Amitabh Monga, Medicine Unit, Department of Medicine, Sitaram Bhartia Institute of Science and Research,

B-16, Mehrauli Institutional Area, New Delhi-110016, India. Telephone 91-11-26867435-38, e-mail mongaamitabh@hotmail.com Received for publication February 10, 2003. Accepted June 17, 2003 
gradually improved over the subsequent five weeks. The hemoglobin mass concentration increased to $98 \mathrm{~g} / \mathrm{L}$, bilirubin fell to $161 \mu \mathrm{mol} / \mathrm{L}$ (conjugated fraction: $99 \mu \mathrm{mol} / \mathrm{L}$ ), AST fell to 176 $\mathrm{U} / \mathrm{L}$, ALT fell to $281 \mathrm{U} / \mathrm{L}$ and reticulocyte count fell to $4.4 \%$. The patient was discharged to be followed in the outpatient department. Ten weeks after the onset of illness the patient's G6PD level was $1.1 \mathrm{U} / \mathrm{gHb}$, and his serum bilirubin and aminotransferase levels were nearly normal. About one month after the onset of illness, the patient's wife, who nursed him through the course of this illness, also developed jaundice and was diagnosed with HEV hepatitis.

\section{DISCUSSION}

Mild hemolysis associated with decreased red blood cell survival may be commonly seen with viral hepatitis, but is seldom of clinical significance $(6,7)$. However, when viral hepatitis occurs in G6PD-deficient patients, hemolysis may be severe $(7,8)$.

The patient described in this case had severe intravascular hemolysis as evidenced by a fall in hemoglobin, reticulocytosis, unconjugated hyperbilirubinemia, hemoglobinuria and undetectable serum haptoglobin levels. The presence of severe hyperbilirubinemia in patients with viral hepatitis and G6PD deficiency has been previously reported (9-11). In a case control study, Gotsman and Muszkat (12) evaluated the impact of G6PD deficiency on patients with Hepatitis A virus infection. They found that although patients with G6PD deficiency had a more severe initial clinical presentation, the clinical outcome was not affected. Abid and Khan (5) recently reported a cohort of five patients from Pakistan with G6PD deficiency and Hepatitis E viral infection. All five patients had severe and protracted illness, and four developed acute renal failure.

Profound hemolysis in G6PD-deficient individuals is usually precipitated by exposure to selected drugs. However, as in this case, viral hepatitis may precipitate massive hemolysis even without the intake of such drugs $(5,7,10)$. The mechanism of hemolysis is thought to occur through decreased levels of reduced glutathione in red blood cells (6). Reduced glutathione levels could result from the accumulation of oxidants

\section{REFERENCES}

1. Das K, Agarwal A, Andrew R, Frosner GG, Kar P. Role of hepatitis E and other hepatotropic virus in etiology of sporadic acute viral hepatitis: A hospital based study from urban Delhi. Eur J Epidemiol 2000;16:937-40.

2. Choudhury VP, Bagga A, Desai N. Increased morbidity of viral hepatitis in patients with G6PD deficiency. J Trop Paed 1992;38:139-40.

3. Agarwal RK, Moudgil A, Kishore K, Srivastava RN, Tandon RK. Acute viral hepatitis, intravascular hemolysis, severe hyperbilirubinemia and renal failure in glucose-6-phosphate dehydrogenase deficient patients. Postgrad Med J 1985;61:971-5.

4. Jolly JG, Sarup BM, Bhatnagar DP, et al. Glucose-6-phosphate dehydrogenase deficiency in India. JIMA 1972;58:196.

5. Abid S, Khan AH. Severe hemolysis and renal failure in glucose-6phosphate dehydrogenase deficient patients with hepatitis E. Am J Gastroenterol 2002;97:1544-7.

6. Pitcher CS, Williams R. Reduced red cell survival in jaundice and its relation to abnormal glutathione metabolism. Clin Sci 1963;24:239.

7. Kattamis CA, Tuortjatou F. The hemolytic process of viral hepatitis in children with normal or deficient glucose-6-phosphate dehydrogenase activity. J Pediatr 1970;77:422-30.

8. Chau TN, Lai ST, Lai JY, Yuen H. Haemolysis complicating acute viral hepatitis in patients with normal or deficient glucose-6-phosphate due to hepatic dysfunction and lead to increased hemolysis in the presence of G6PD deficiency. Despite the high levels of bilirubin in these patients, the prognosis is mainly related to the severity of hepatic injury (9). Acute renal insufficiency, though uncommon in uncomplicated acute viral hepatitis, can occur as a fatal complication of severe intravascular hemolysis in these patients (3). Excess hematin and bilirubin may result in the obstruction of renal tubules, leading to acute renal insufficiency with increased morbidity. Renal failure may be nonoliguric,; therefore, kidney function should be assessed by regularly monitoring blood chemistry, and urinary sodium and osmolarity. Measures to prevent renal failure include maintaining good hydration and adequate urine output, and avoiding nephrotoxic drugs.

HEV infection is transmitted through the feco-oral route but, unlike other enteric agents, does not generally spread from infected persons to their close contacts (13). In the present case, one month after the onset of jaundice in the patient his wife also contracted HEV. Because the incubation period of HEV ranges from 14 to 60 days, it is likely that she contracted the virus from her husband, rather than from a common source.

In patients with acute viral hepatitis and unexplained anemia with very high serum bilirubin levels, intravascular hemolysis should be considered and investigated. Wilson's disease may present with jaundice and hemolysis and must be excluded. Tests for G6PD deficiency may be negative during and immediately after a hemolytic episode because the old red blood cells deficient in G6PD have been hemolysed and the higher content of G6DP in the new red blood cells may lead to false normal levels. A repeat test should be done eight to 10 weeks after the disease resolves. When G6PD deficiency is suspected, treatment with vitamin $\mathrm{K}$ should be avoided because it may further aggravate hemolysis (14). Finally, all G6PD-deficient individuals should be vaccinated against Hepatitis A and B. Universal immunization against HAV and HBV for communities with high prevalences of G6PD deficiencies (eg, VataliyaPrajapati community in western India [15], Muria gonds of central India [16], etc) should also be considered.

dehydrogenase activity. Scand J Infect Dis 1997;28:551-3.

9. Clearfield HR, Brody JI, Tumen HJ. Acute viral hepatitis, glucose-6phosphate dehydrogenase deficiency and hemolytic anemia. Arch Int Med 1969;123:689.

10. Salen G, Goldstein F, Hanrani F, et al. Acute hemolytic anemia complicating acute viral hepatitis in patients with glucose-6-phosphate dehydrogenase deficiency. Ann Int Med 1966;65:1210.

11. Morrow RH, Smetana HF, Sai FT, et al. Unusual features of viral hepatitis in Accra, Ghana. Ann Int Med 1968;68:1250.

12. Gotsman I, Muszkat M. Glucose-6-phosphate dehydrogenase deficiency is associated with increased initial clinical severity of acute viral hepatitis A. J Gastroenterol Hepatol 2001;16:1239-43.

13. Jules LD, Kurt JI. Acute viral hepatitis. In: Harrison's Principles of Internal Medicine, 15th ed. McGraw-Hill, New York:2001;1721-37.

14. Bunn HF, Rosse W. Hemolytic anemias and acute blood loss. In: Harrison's Principles of Internal Medicine, 15th ed. McGraw-Hill, New York:2001;681-92.

15. Joshi SR, Patel RZ, Patel HR, Sukumar S, Colah RB. High prevalence of G6PD deficiency in Vataliya Prajapati community in Western India. Haematologia (Budap) 2001;31:57-60.

16. Thakur A, Verma IC. Interaction of malaria infection and glucose-6phosphate dehydrogenase deficiency in Muria gonds of district Bastar, central India. Trop Geogr Med 1992;44:201-5. 


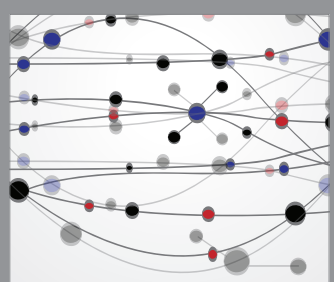

The Scientific World Journal
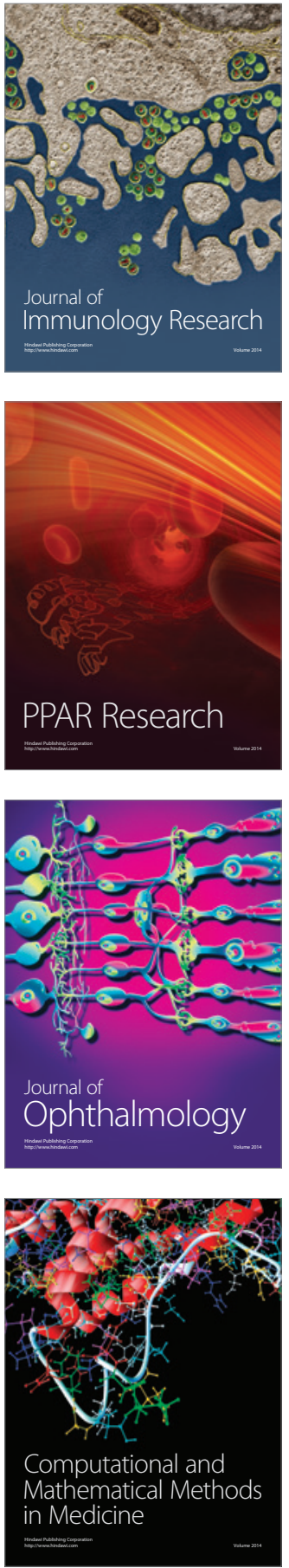

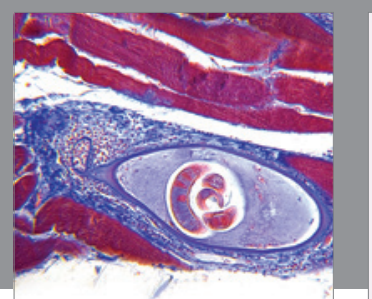

Gastroenterology Research and Practice

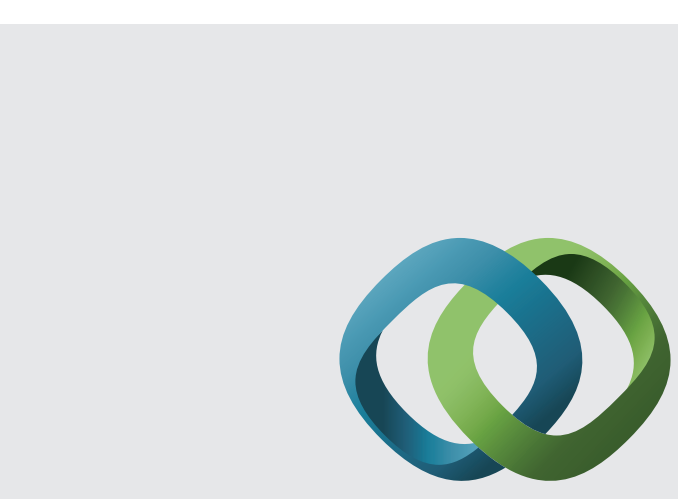

\section{Hindawi}

Submit your manuscripts at

http://www.hindawi.com
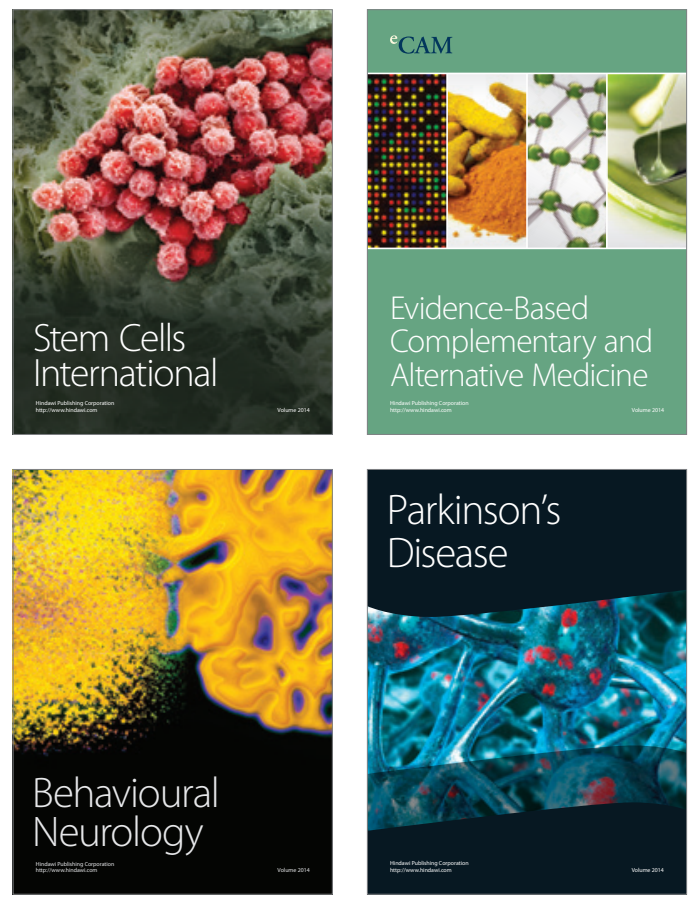
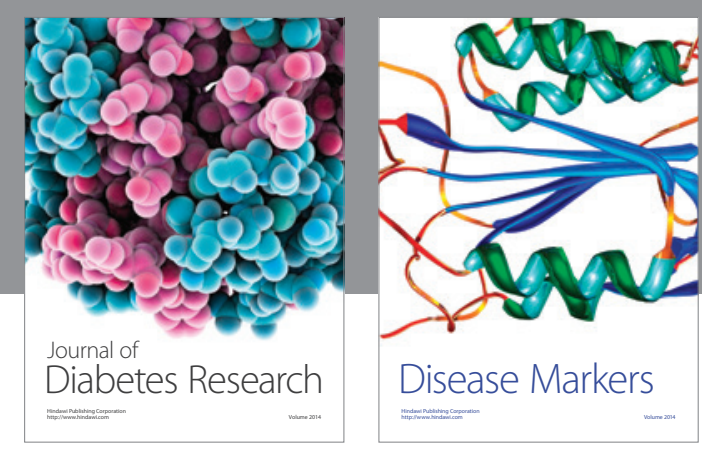

Disease Markers
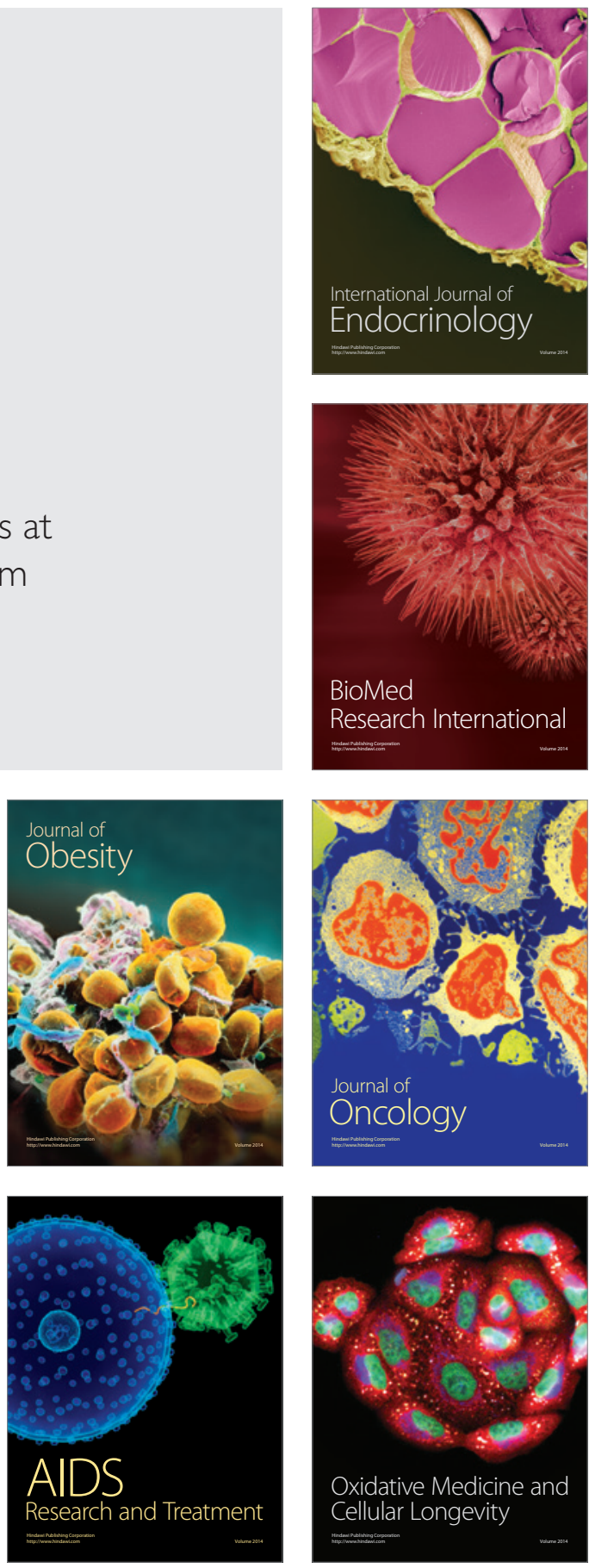